\title{
FIELD PERFORMANCES OF DIFFERENT SEEDLING TYPES USED IN SWEET POTATO [Ipomea batatas (L.) Lam] GROWING
}

\author{
Gulsum OZTURK \\ Ege University, Faculty of Agriculture, Department of Field Crops, Bornova-IZMIR, TURKEY \\ Corresponding author: gulsum.ozturk@ege.edu.tr
}

Received: 25.12 .2020

\begin{abstract}
The purpose of the study was to compare field performances of three sweet potato seedlings such as in vitro plantlets (IP) rooted cuttings (RC) and cuttings (C). A field trial in the Randomized Complete Block Design (RCBD) with 3 replications arranged in Split Plots (SP) was conducted in 2016 and 2017 in the experimental field of the Ege University located at Bornova. The following results based on the analysis of data could be summarized: In vitro plantlets had the higher mean for the number of storage roots (8.4), single storage root weight $(684.1 \mathrm{~g})$, single plant yield $(5.2 \mathrm{~kg})$ and plot yield $(37.0 \mathrm{~kg})$. Genotype Lanceolado had high storage root number. Genotype Yan Shu-1 had high means for single storage root weight $(809.8 \mathrm{~g})$, single plant yield $(5.9$ kg) and plot yield $(43.3 \mathrm{~kg})$.
\end{abstract}

Keywords: In vitro plantlets, root cuttings, cuttings, sweet potato

\section{INTRODUCTION}

Sweet potato [Ipomea batatas (L.) Lam], a native of central America has been grown widely in the tropic, subtropic and temperate climatical regions of the world following after rice, cereals, potatoes and cassava (Alam et al., 2010; Dugassa and Feyissa, 2011). Although sweet potatoes have been introduced to Turkey over Cyprus it has only been grown in Hatay Province of Turkey. Caliskan et al. (2020) reported approximately 100-150 ha production area and average yield $1.439 \mathrm{~kg} \mathrm{ha}^{-1}$ in Turkey.

Green parts of sweet potato are rich in protein (Kodjo et al., 2013) so they were used as animal feed and silage (Monteiro et al., 2007; Kebede et al., 2008; Geren et al., 2010). Fresh leaves of sweet potato are also used in salads. Jumbo type sweet potatoes are utilized in starch, alcohol, baby food, food coloring and biodiesel production industry. Storage roots are rich in vitamin A, $\beta$-carotene and antioxidants. Hence storage roots with orange color are preferred due to high vitamin A contents (Yildirim et al., 2011; Ogero et al., 2012).

Growing of sweet potato is realized by using storage roots and seedlings (Dugassa and Feyissa, 2011). Wilson (1988) stressed that healthy plant material should be used in sweet potato propagation for high yield. So the grower should consider type, length, age and health of the initial material. Sweet potato is also propagated by using vine cuttings taking from young plants. Storage root sprouts and first cuttings have also been used as seedlings instead of vine cutting (Hall, 1993; Braun, 2001). In practice seedlings obtained from main stems are used widely
(Novak et al., 2007). In general, storage roots are grown in seedbeds at 25-30 $\mathrm{C}^{0}$ to obtain seedlings and these seedlings are planted in the field (Novak et al., 2007; Dugassa and Feyissa, 2011). Under cold conditions, the growing is realized by using storage roots since seedling production is not possible due to low temperatures. In large growing areas; there are difficulties in providing sufficient seed material as seedlings from storage roots. Viruses are carried with storage roots resulting in yield losses (Alcenoro, 1975; Jarret, 1990). For that reason tissue culture techniques have been proposed and used in reducing the negative effects of classical production methods by using storage roots or sprouts. Using the tissue culture, healthy seedlings are obtained by taking the apical and axillary buds in vitro in the laboratory. These seedlings could be used in field production instead of traditional growing. The advantage of in vitro technics is production of healthy and uniform material in a short period, low expenses and avoiding adverse environmental effects (Jarret, 1990; Lizarraga et al., 1992; Ahloowalia et al., 2004; Alberto Cruz-Crus, 2013; Dolinski and Olek, 2013; Kodjo et al., 2013). The in vitro plantlets could be sub-cultured at certain periods to produce disease free seedlings (Reed et al., 2004). Since the acclimatization of in vitro seedlings is easy, good rooting and stem development could be provided in this way (Pospisilova et al., 1999; Novac et al., 2007; Kodjo et al., 2013).

The purpose of this study was to compare the field performances of in vitro seedlings (IP) obtained in the laboratory, root cuttings (RC), and only cuttings (C) in the field trial. 


\section{MATERIALS AND METHODS}

This study was conducted in the Tissue Culture Laboratory, greenhouse and experimental field of the
Field Crops Department of the Ege University in 2016 and in 2017.

The characteristics of the sweet potato genotypes used as genetic material in the study are shown in Table 1.

Table 1. Sweet potato genotypes used in the study*

\begin{tabular}{lll}
\hline Genotype & Origin & Known characteristics \\
\hline Yan Shu-1 & China & Spread, long-elliptic, red, creme flesh \\
Tamayukata & Japan & Erect, round-elliptic, creme, dark creme flesh \\
Lanceolado & Peru & Erect, long-elliptic, purple, creme flesh \\
\hline ": obtained from the CIP &
\end{tabular}

: obtained from the CIP

\section{Obtaining of in vitro plantlets (IP)}

Storage roots of three sweet potatoes were grown in pots in the greenhouse to produce seedlings in 2015. Seedlings $1 \mathrm{~cm}$ in length were kept in $70 \%$ ethyl alcohol and $2.5 \%$ sodium hypochlorite $(\mathrm{NaOCl})$ solution for surface sterilization. Two different media of MS (Murashige and Skoog, 1962) were used. First medium is $2 \mathrm{mg} / 1$ NAA (1Naphthaleneacetic acid), $0.1 \mathrm{mg} / \mathrm{G} \mathrm{GA}_{3}$ (Gibberellic acid) $20 \%$ sucrose. Axillary buds $0.5 \mathrm{~cm}$ in length were taken from each genotype and they were cultured test tubes in $15 \times 2.5 \mathrm{~cm}$. After 10-12 weeks, cultures were transferred to $\mathrm{MS}+1 \mathrm{mg} / \mathrm{l}$ NAA medium described by Yildirim et al. (2011) for nodal multiplication. The micro seedlings were left to develop in the culture until they were $5-6 \mathrm{~cm}$ in length with roots. In vitro plantlets were taken out from the medium and they were left to acclimatization. Then in vitro plantlets were planted in plastic pots containing sterile soil + turf in $2: 2$ ratios and they were left to development for 2 weeks.

\section{Obtaining root cuttings $(R C)$ and cuttings $(C)$}

Storage roots were planted in plastic cages containing soil and turf mixture on February 02, 2016 and they were left to development. Approximately $8-10 \mathrm{~cm}$ rooted cutting $(\mathrm{RC})$ and cuttings without root $(\mathrm{C})$ were used in the field trial.

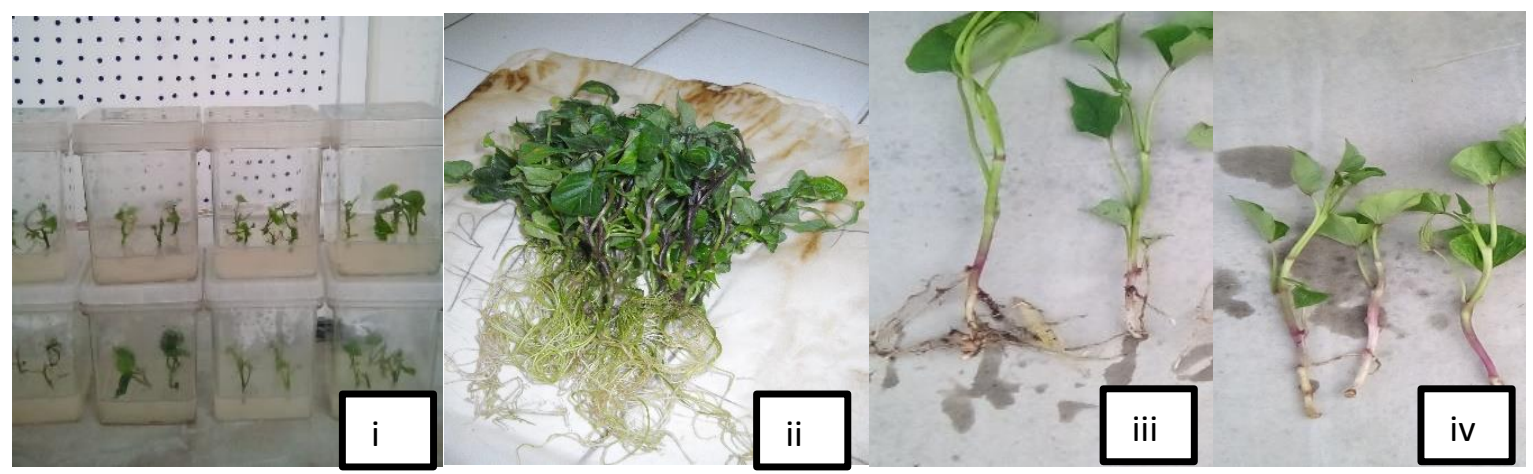

Figure 1. i: in vitro nodal propagation, ii: in vitro seedlings, iii: rooted cutting, iv: cuttings

\section{Climatical and soil characteristics of the experimental area}

Average temperature $\mathrm{C}^{0}$ and total precipitation (mm) of the experimental site are shown in Table 2. Soil characteristics of the experimental area are given in Table 3 .

\section{Field trial}

Seedlings of three different seedlings types of 3 genotypes were transplanted in the field trial on April 20, 2016 and 2017. The design of the trial was the
Randomized Complete Block Design (RCBD) with 3 replications arranged in Split Plots (SP). Plot size was 2 rows in $3 \mathrm{~m}$ length with $80 \mathrm{~cm} \times 60 \mathrm{~cm}$ spacing. Since sweet potatoes are not grown in the region we accepted $\mathrm{C}$ seedlings as control. Composite fertilizers (15\%-15\%$15 \%, \mathrm{NPK}$ ) and after hilling DAP (diammonium phosphate) were applied at dose of $10 \mathrm{~kg}$ da and $5 \mathrm{~kg}$ da, respectively. Cultural methods were applied and the trial was harvested on November 4, 2016 and November 3, 2017 by hand. After harvest, the number of the storage root, single storage root weight $(\mathrm{g})$, single plant yield $(\mathrm{kg})$ and plot yield $(\mathrm{kg})$ were measured and recorded. 
Table 2. Temperature and total precipitation in Bornova-Izmir-Turkey during the 2016 and 2017 growing seasons*

\begin{tabular}{lcccc}
\hline \multirow{2}{*}{ Months } & \multicolumn{2}{c}{$\mathbf{2 0 1 6}$} & \multicolumn{2}{c}{$\mathbf{2 0 1 7}$} \\
\cline { 2 - 5 } & \multicolumn{2}{c}{ Average Temperature $\left(\mathbf{C}^{\mathbf{0}}\right)$} & 16.6 & 15.7 \\
\hline April & 18.9 & 12.8 & 21.7 & 27.0 \\
\hline May & 21.2 & 28.2 & 26.5 & 1.8 \\
\hline June & 27.7 & 9.2 & 29.8 & 1.4 \\
\hline July & 29.9 & 1.2 & 29.4 & 0.3 \\
\hline August & 29.4 & 3.0 & 24.6 & 0.9 \\
\hline September & 25.1 & 6.4 & 18.8 & 45.7 \\
\hline October & 19.2 & 1.4 & 13.3 & 62.1 \\
\hline November & 14.0 & 100.6 & & \\
\hline
\end{tabular}

Table 3. Soil characteristics of the experimental field

\begin{tabular}{ccc}
\hline Physical and Chemical traits & Evaluation & Method \\
\hline $\mathrm{pH}$ & Slightly alkaline & Jackson, 1967 \\
\hline Organic Matter $(\%)$ & Low & Jackson, 1967 \\
\hline Lime (\%) & Calcerous & Schlichting and Blume, 1966 \\
\hline Sand (\%) & & Bouyoucos, 1962 \\
Clay (\%) & Clay loam & \\
\hline Silt $(\%)$ & Middle & Bremner, 1965 \\
\hline Total N $(\%)$ & Enough & Olsen, 1982 \\
\hline $\mathrm{P}(\mathrm{mg} / \mathrm{kg})$ & High & Pratt, 1965
\end{tabular}

\section{Statistical analysis}

The data obtained in the field trials run in 2016 and 2017 were analyzed by using standard statistical procedures of Split Plot arrangement described by Acikgoz et al. (2004). The significance of variation was tested by the $\mathrm{F}$ test and the means were compared by using the standard LSD test described by Steel and Torrie (1980).

\section{RESULTS AND DISCUSSION}

The mean squares and their significance based on $\mathrm{F}$ values of the three different seedling types are shown in Table 4.

Table 4. Means squares of the yield characteristics obtained from the combined analysis of variance over 2016 and 2017.

\begin{tabular}{lcllll}
\hline Source of variation & $\begin{array}{l}\text { Degree of } \\
\text { freedom }\end{array}$ & $\begin{array}{l}\text { Number of storage } \\
\text { root }\end{array}$ & $\begin{array}{l}\text { Single storage root } \\
\text { weight (g) }\end{array}$ & $\begin{array}{l}\text { Single plant yield } \\
(\mathbf{k g})\end{array}$ & $\begin{array}{l}\text { Plot yield } \\
(\mathbf{k g})\end{array}$ \\
\hline Year & 1 & $1.05^{\mathrm{ns}}$ & $2.01^{\mathrm{ns}}$ & $3.224^{\mathrm{ns}}$ & $2.411^{\mathrm{ns}}$ \\
Genotype & 2 & $162.8^{* *}$ & $14738^{* *}$ & $748.976^{* *}$ & $1147.8^{* *}$ \\
Genotype x year & 2 & $0.116^{\mathrm{ns}}$ & $0.795^{\mathrm{ns}}$ & $1.0408^{\mathrm{ns}}$ & $1.579^{\mathrm{ns}}$ \\
Error 1 & 12 & & & $1258^{* *}$ & $717.44^{* *}$ \\
Seedlings & 2 & $742.6^{* *}$ & $715.5^{* *}$ & $57.024^{* *}$ & $19.58^{* *}$ \\
Genotypes x Seedlings & 4 & $312.0^{* *}$ & $25.12^{* *}$ & $3.102^{\mathrm{ns}}$ & $0.056^{\mathrm{ns}}$ \\
Seedlings x year & 2 & $8.24^{* *}$ & $1.500^{\mathrm{ns}}$ & $3.98^{\mathrm{ns}}$ & $0.493^{\mathrm{ns}}$ \\
Genotypes x seedlings & 4 & $7.39^{* *}$ & $1.185^{\mathrm{ns}}$ & & \\
x year & & & & \\
Error 2 & 24 & & &
\end{tabular}

*: significant at the 0.05 probability level

**: significant at the 0.01 probability level

ns: non-significant

It could be seen in Table 4 that genotype, seedlings and genotype $\mathrm{x}$ seedlings interaction had highly significant variation for all traits studied at the $\mathrm{p} \leq 0.01$ level. So the means of the traits over two years will be discussed for seedlings and genotypes together. Only seedlings $\mathrm{x}$ year interaction had significant variation at the $\mathrm{p} \leq 0.01$ level for number of storage roots and the genotypes $\mathrm{x}$ seedlings $\mathrm{x}$ year second order interaction was significant at the $p \leq 0.05$ level for number of storage roots.
This could be due to the genotype seedlings interaction. Due to this an expected situation two way table will be used in discussion. Means of seedlings type of genotypes for yield characteristics are shown in Table 5. 
Table 5. The means of yield characteristics for seedlings of 3 genotype observed in field trial run in 2016 and 2017

\begin{tabular}{|c|c|c|c|c|c|c|c|c|c|c|c|c|c|c|c|c|c|c|c|}
\hline \multirow[t]{3}{*}{ Genotypes } & \multicolumn{7}{|c|}{ Number of storage roots ${ }^{*}$} & \multicolumn{4}{|c|}{ Single storage root weight $(\mathrm{g})$} & \multicolumn{4}{|c|}{ Single plant yield (kg) } & \multicolumn{4}{|c|}{ Plot yield (kg) } \\
\hline & \multicolumn{2}{|c|}{$\mathrm{IP}^{1}$} & \multicolumn{2}{|c|}{$\mathrm{RC}^{2}$} & \multicolumn{2}{|c|}{$\mathrm{C}^{3}$} & \multirow{2}{*}{ Mean } & \multirow{2}{*}{$\mathrm{IP}^{1}$} & \multirow[t]{2}{*}{$\mathrm{RC}^{2}$} & \multirow[t]{2}{*}{$\mathrm{C}^{3}$} & \multirow{2}{*}{ Mean } & \multirow{2}{*}{$\mathrm{IP}^{1}$} & \multirow{2}{*}{$\mathrm{RC}^{2}$} & \multirow{2}{*}{$\mathrm{C}^{3}$} & \multirow[t]{2}{*}{ Mean } & \multirow[t]{2}{*}{$\mathrm{IP}^{1}$} & \multirow{2}{*}{$\mathrm{RC}^{2}$} & \multirow{2}{*}{$\mathrm{C}^{3}$} & \multirow[t]{2}{*}{ Mear } \\
\hline & 2016 & $\underline{2017}$ & 2016 & 2017 & $\underline{2016}$ & 2017 & & & & & & & & & & & & & \\
\hline Yan Shu-1 & $\overline{7.8}$ & $\overline{8.0}$ & $\overline{7.0}$ & $\overline{7.0}$ & $\overline{7.0}$ & 6.2 & 7.2 & 962.2 & 806.5 & 660.7 & $\underline{809.8}$ & 7.7 & 5.6 & 4.3 & $\underline{5.9}$ & 55.3 & 41.7 & 33.0 & 43.3 \\
\hline Tamayukata & 5.8 & 5.3 & 5.0 & 5.5 & 5.2 & 5.0 & 5.3 & 770.0 & 627.0 & 559.8 & 652.3 & 4.2 & 3.2 & 2.7 & 3.4 & 31.7 & 24.3 & 18.5 & 24.8 \\
\hline Lanceolado & 11.8 & 11.3 & 8.2 & 8.2 & 5.7 & 5.7 & $\underline{8.5}$ & 320.0 & 235.0 & 155.5 & 236.8 & 3.7 & 1.9 & 0.8 & 2.1 & 23.9 & 15.8 & 8.5 & 16.1 \\
\hline Mean & 8.5 & 8.2 & 6.7 & 6.9 & 6.0 & 5.6 & & 684.1 & 556.2 & 458.7 & & 5.2 & 3.6 & 2.6 & & 37.0 & 27.2 & 20.0 & \\
\hline $\operatorname{LSD}_{(0.05)}$ & & & 0.3 & & & & & & 13 & 021 & & & & .369 & & & & 193 & \\
\hline
\end{tabular}

${ }^{1}:$ in vitro plantlets from storage roots

2: rooted cutting from storage roots

3.

$*$ : interaction was signifint

Table 6. Means of the characteristics for seedlings based on field trial run in 2016 and 2017

\begin{tabular}{|c|c|c|c|c|c|}
\hline \multirow[t]{2}{*}{ Seedlings } & \multicolumn{2}{|c|}{ Number of storage roots } & \multirow[t]{2}{*}{ Single storage root weight (g) } & \multirow[t]{2}{*}{ Single plant yield (kg) } & \multirow[t]{2}{*}{ Plot yield (kg) } \\
\hline & 2016 & $\underline{2017}$ & & & \\
\hline IP (in vitro plantlets) & $\overline{8.5}$ & $\overline{8.2}$ & 684.1 & 5.2 & 37.0 \\
\hline RC (Rooted cuttings) & 6.7 & 6.9 & 556.2 & 3.6 & 27.2 \\
\hline C (Cuttings) & 6.0 & 5.6 & 458.7 & 2.6 & 20.0 \\
\hline $\operatorname{LSD}_{(0.05)}$ & \multicolumn{2}{|c|}{0.202} & 7.517 & 0.213 & 1.266 \\
\hline
\end{tabular}


It could be seen in Table 5 means of in vitro plantlets for number of storage root, single storage root weight $(\mathrm{g})$, single plant yield $(\mathrm{kg})$ and plot yield $(\mathrm{kg})$ had significant LSD values supporting significant statistical differences among them. For storage root number, in vitro plantlets had high mean (8.4) than that of other seedling types. We can also observe this permanent trend for other characteristics such as $684.1 \mathrm{~g}$ for single storage root weight $5.2 \mathrm{~kg}$ for single plant yield and $37.0 \mathrm{~kg}$ for plot yield.

Genotype Lanceolado (8.5) had high mean for number of storage root; genotype Yan Shu-1 had high mean for single storage root weight (809.8 g), single plant yield (5.9 $\mathrm{kg})$ and plot yield $(43.3 \mathrm{~kg})$.

When the means of the seedlings types in Table 5 were evaluated; in vitro plantlets (IP) had higher means than those of the rooted cuttings (RC) and cuttings (C). Genotype Yan Shu-1 and Tamayukata had high mean for single storage root weight, single plant yield and plot yield. Genotype Lanceolado had high means for number of storage roots except of cuttings (C). This genotype has been offered as consumption due to its standard type storage roots and it is expected to have low yield. Saiful et al. (2002) has reported high yield from single node leaf cuttings in the field experiment. They explain this situation with early development due to rooted system and reaching to high photosynthesis rate earlier. In our study in vitro plantlets (IP) have started early vegetative development as compared to other two seedlings types so they resulted in high means for the characteristics. Novak et al. (2007) compared the seedlings obtained directly from root sprouts and young root slips and obtained higher yield from young root slips. In this study the IP seedlings obtained young axillary buds and had a fast and healthy growth potential compared to rooted cutting and cuttings. So IP seedlings had the high means for the characteristics studied.

Saiful et al. (2002) and Novak et al. (2007) have reported the high yield from root cuttings. It could be seen in table 6 that the RC (Rooted cutting) had high mean for the traits studied. The IP (in vitro plantlets) had higher yield than the RC (Rooted cutting) in this study indicating high yield in sweet potato grown. Yildirim et al. (2012) have also stated the highest yield from in vitro plantlets compared to the seed roots. They pointed out that in vitro plantlets developing earlier than the seed roots.

It could be seen that in vitro plantlets (IP) had apparent superiority over rooted cuttings (RC) and cuttings (C) for the characteristics studied so the IP seedlings could be used in sweet potato propagation. Besides, genetically uniform, disease-free and healthy seedling can be produced by using in vitro plantlets in all growing seasons.

\section{CONCLUSION}

In vitro plantlets (IP) were found to have higher means of storage root characteristics as compared to the RC
(Rooted cutting) and C (cuttings) type seedlings. Therefore in vitro plantlets could be used as seedlings in sweet potato propagation to obtain high yields of storage roots.

\section{LITERATURE CITED}

Acikgoz, N., E. Ilker, A. Gokcol. 2004. Evaluation of biological research in computer. E.U. TOTEM, Publication No:2, Izmir (in Turkish).

Ahloowalia, B.S. 2004. Integration of technology from lab to land, Proceedings of a Technical Meeting organized by the Joint FAO/IAEA Division of Nuclear Techniques in Food and Agriculture and held in Vienna, 26-30 August, 2004.

Alberto Cruz-Cruz, C., M.T. González-Arnao, F. Engelmann. 2013. Biotechnology and Conservation of Plant Biodiversity. Resources 2: 73-95.

Alcerono, R., A.G. Santiago, F. Morales, F. Rodriguez. 1975. Meristem tip culture and virus indexing of sweet potatoes. Phytopathology 65: 769-773.

Alam, I., S.A. Sharmin, M.K. Naher, M.J. Alam, M. Anissuzzaman, M.F. Alam. 2010. Effect of growth regulators on meristem culture and plantlet establishment in sweet potato [Ipomoea batatas (L.) Lam.]. POJ. 3 (2):35-39.

Braun, B. 2001. The maintenance of sweetpotato planting materials in Namibia: options for the development of a vine production and distribution system. Agricola. p.15-20.

Caliskan, M.E. S. Caliskan, U. Demirel, E. Aksoy, H.H. Arioglu. 2020. Starch and sugar plants production current and future, Turkey Agricultural Engineering IX. Technical Congress, p.453.

Doliński, R. and A. Olek. 2013. Micropropagation of Sweet Potato (Ipomoea batatas (L.) Lam.) from Node Explant. Acta Sci. Pol. Hortorum Culturs 12 (4): 117-127.

Dugassa, G. and T. Feyissa. 2011. In Vitro Production of VirüsFree Sweet Potato [Ipomea batatas (L.) Lam] by Meristem Culture and Termotherapy. Ethiop. J. Sci. 34(1): 17-28.

Geren, H., G. Ozturk, Y.T. Kavut, Z. Yildirim. 2010. An investigation on silage possibilities of vines of sweet potato (Ipomea batatas L.) genotypes grown under Bornova conditions. Journal of Ege University Faculty of Agriculture 47(2): 171-179.

Hall, M.R. 1993. Yielding comparisons of pulled and cut sweet potato plants. Hortscience 28: 703-704.

Jarret, R.L. 1990. In Vitro Active vs. Field Gene bank Maintenance of Sweet Potato Germplasm: Major Costs and Considerations. HortScience 25 (2).

Kebede, T., T. Lemma, E. Tadesse, M. Guru, 2008. Effect of level of substitution of sweet potato (Ipomoea Batatas. L) vines for concentrate on body weight gain and carcass characteristics of browsing Arsi-Bale goats. Journal of Cell and Animal Biology 2 (2): 36-42.

Kodjo, G., E.K. Djidjolé, S. Mensah, T. Koffi, A. Atsou. 2013. Comparison of in vitro morphogenetic capacities of different clones of three local cultivars of sweet potato (Ipomoea batatas) from Togo. African Journal of Biotechnology 12 (29): 4648-4655.

Lizarraga, R., A. Panta, N. Espinoza, J.H. Dodds. 1992. Tissue culture of Ipomoea batatas: micropropagation and maintenance. CIP Research Guise p.32.

Monteiro, A.B., A.J. Massaroto, C.F. Gasparino, R.R. Silva, L.A. Gomes, W.R. Maluf, J.C.S. Filho. 2007. Cultivate and clones ensilage of sweet potato for animal food to coming the sustainable of the familiar agricultural production. Rev. Bras. de Agroecologia. 2 (2). 
Murashige, T. and F. Skoog. 1962. A revised medium for rapid growth and bioassay with tobacco cultures. Physiol. Plant. 15:473-479.

Novac B., I. Žutić, N. Toth, N. Dobričević. 2007. Sweet potato (Ipomoea batatas (L.) Lam.) yield influenced by seedlings and mulching. Agric. Conspec. Sci. 72(4): 357-359.

Ogero,K.O., G.N. Mburugu, M. Mwangi, M.M. Ngugi, O. Ombori. 2012. Low Cost Tissue Culture Technology in the Regeneration of Sweet Potato (Ipomoea batatas (L) Lam). Research Journal of Biology 2(2): 51-58.

Ozturk, G., F.N. Azeri, Z. Yildirim. 2012. Field performance of in vitro sweet potato [Ipomoea batatas (L.) Lam] plantlets derived from seed stocks. Turk J Field Crops. 17 (1): 1-4.

Pospisilova, J., I. Ticha, P. Kadlecek, D. Haisel, S. Plzakova. 1999. Acclimatization of micropropagated plants to ex vitro conditions. Biologia Plantarum 42 (4): 481-497.
Reed, B.M., F. Engelmann, M.E. Dulloo, J.M.M. Engels. 2004. Technical guidelines for the

management of field and in vitro germplasm collections. IPGRI Handbooks for Genebanks No. 7.

Saiful Islam, A.F.M, C. Kubota, M. Takagaki, T. Kozai. 2002. Sweetpotato Growth and Yield from Plug Transplants of Different Volumes, Planted Intact or Without Roots. Crop Science 42: 822-826.

Steel, R.G.D. and J.H. Torrie. 1980. Principles and Procedures of Statistics, McGaw-Hill Book Company, Inc. N.Y.

Yildirim, Z., O. Tokusoglu, G. Ozturk. 2011. Determination of Sweet potato [Ipomoea batatas (L.) Lam] Genotypes Suitable to the Aegean Region of Turkey. Turk J Field Crops. 16 (1): 48-53.

Wilson J.E. 1988. Sweet potato (Ipomoea batatas) planting materials. IRETA Publications. 2(88):1-10. 